\title{
Pengembangan Sistem Inventory Praktikum Pemesinan Berbasis Web di Laboratorium Pemesinan Jurusan Teknik Mesin Fakultas Teknik Universitas Negeri Malang
}

\author{
Febri Eko Wijanarko ${ }^{1}$, Imam Sudjono ${ }^{2}$, Agus Suyetno ${ }^{3}$ \\ ${ }^{1,2,3}$ Program Studi S1 Pendidikan Teknik Mesin Jurusan Teknik Mesin \\ ${ }^{1,2,3}$ Fakultas Teknik Universitas Negeri Malang \\ E-mail: febri.few@gmail.com ${ }^{1}$
}

\begin{abstract}
Abstrak: Penelitian dan pengembangan ini bertujuan untuk membuat program sistem inventory praktikum pemesinan berbasis web yang dapat membantu laboran dan mahasiswa dalam proses peminjaman peralatan praktikum, serta mempermudah laboran dalam memonitoring dan mendata semua peralatan yang terdapat di laboratorium pemesinan. Dalam penelitian ini dilakukan validasi terhadap program yang telah dikembangkan dengan melibatkan dua para ahli, yaitu ahli materi dan ahli media. Validasi dilakukan untuk mengetahui kelayakan dari program yang telah dikembangan sebelum nantinya di uji cobakan kepada mahasiswa jurusan teknik mesin. Hasil uji coba produk oleh responden terdapat dua aspek yang dinilai yaitu, aspek materi dan aspek media. Skor yang didapatkan dari aspek materi adalah 96,25\% dan 96,125\% diperoleh dari aspek media, sehingga skor total yang didapatkan dari uji coba ke mahasiswa jurusan teknik mesin adalah $96,18 \%$.
\end{abstract}

Kata kunci: sistem inventory, praktikum pemesinan, web

\begin{abstract}
This research aims to create a web-based machining practicum inventory system program that can assist laboratory assistants and students in the process of borrowing practicum equipment, as well as facilitate laboratory assistants in monitoring and registering all equipment contained in the machining laboratory. In this study, the validation of the program has been developed by involving two experts, namely material experts and media experts. Validation have been use to determine the feasibility of the program that has been developed before it will be tested on students majoring in mechanical engineering. The results of trials product by respondents, there are two aspects which are assessed namely, material aspects and media aspects. The score obtained from the material aspect was $96.25 \%$ and $96.125 \%$ was obtained from the media aspect, so the total score obtained from trials to students majoring in mechanical engineering was $96.18 \%$.
\end{abstract}

Key words: inventory system, machining practicum, web

Lab pemesinan merupakan fasilitas yang sangat penting di Universitas Negeri Malang khususnya di jurusan Teknik Mesin. Pada hakikatnya lab pemesinan merupakan tempat berlatih untuk meningkatkan keterampilan baik dalam pembuatan benda kerja maupun untuk pengujian kebenaran suatu teori yang ditunjang dengan adanya peralatan dan infrastruktur yang lengkap. Menurut Didik (2012: 23), lab pemesinan harus memenuhi standar sarana dan prasarana agar tujuan tercapai. Pada kerja praktik pemesinan, setiap mahasiswa difasilitasi dengan mesin dan kelengkapan kerja lainnya. Pada lab pemesinan di Universitas Negeri Malang terdapat mesin-mesin yang sudah ditata sesuai dengan kegiatan praktik seperti mesin bubut, mesin frais, mesin gerinda dan lain-lain. Adapun kelengkapan kerja lainnya disimpan secara terpusat di tempat penyimpanan alat peralatan praktikum.

Menurut Ristono (2009:1) inventory atau persediaan adalah suatu teknik untuk manajemen material yang berkaitan dengan persediaan yang ada di dalam gudang atau bengkel. Manajemen material dalam inventory dilakukan dengan beberapa input yang digunakan yaitu: permintaan yang terjadi, biaya-biaya yang terkait dengan penyimpanan dan biaya apabila terjadi kekurangan persediaan. Secara teknis, inventory adalah suatu teknik yang berkaitan dengan penetapan terhadap persediaan bahan yang harus disediakan guna menjamin kelancaran proses produksi. 
Pada tempat peralatan praktikum dikhususkan untuk mengolah alat kerja yang membantu kegiatan praktikum mahasiswa jurusan Teknik Mesin. Tempat peralatan merupakan tempat dimana mahasiswa melakukan kegiatan peminjaman alat kerja (Indra, 2013: 6). Proses penyimpanan dan administrasi peminjaman alat kerja ini dilayani oleh seorang petugas yang disebut dengan toolman. Setiap mahasiswa yang sedang melaksanakan praktikum akan meminjam alat melalui toolman. Pada lab pemesinan ada beberapa tempat peralatan yang di dalamnya terdapat alat-alat kerja. Alat-alat yang disimpan di masingmasing tempat alat berbeda-beda dan semua mahasiswa yang melaksanakan praktikum diperbolehkan meminjam alat kerja yang dibutuhkannya.

Pengelolaan alat kerja dan proses peminjaman di semua tempat peralatan yang berada di lab pemesinan Jurusan Teknik Mesin Universitas Negeri Malang masih bersifat manual. Pada proses peminjaman alat mahasiswa akan menuju ke laboran untuk meminjam alat yang dibutuhkan. Namun terdapat beberapa kesulitan yang sering dialami oleh mahasiswa terkait dengan proses peminjaman alat kerja. Kesulitan-kesulitan tersebut dikelompokkan dalam dua kelompok yaitu teknis dan administratif.

Menurut Gregorius (2012: 25), kelompok teknis merupakan kesulitan - kesulitan yang disebabkan oleh kondisi teknis, yang berkaitan erat dengan kondisi alat kerja, persediaan dan keterbatasan alat kerja yang tersedia saat ini, salah satu hal yang sering terjadi adalah rusaknya peralatan kerja yang diakibatkan oleh kurang tanggung jawabnya mahasiswa terhadap peralatan yang dipinjam, sedangkan kelompok administratif merupakan kesulitan-kesulitan yang disebabkan oleh kegiatan administrasi dan kualitas pelayanan dalam proses peminjaman. Kesulitan administratif yang paling sering dialami mahasiswa adalah terhambatnya proses peminjaman bila toolman sedang tidak berada di tempat. Proses peminjaman yang lebih lama akan menghambat kegiatan praktikum yang dilakukan mahasiswa.

Informasi mengenai persediaan dan kondisi dari alat kerja tidak dapat terpantau dengan baik dan sulit untuk diakses karena pengelolaan dilakukan dengan cara manual. Hal tersebut dapat dibuktikan dengan penyebaran angket yang dilakukan oleh peneliti untuk membuktikan dan mencari akar permasalahan yang terjadi, angket yang dimaksud adalah angket analisis kebutuhan yang telah disebarkan pada 20 mahasiswa teknik mesin Universitas Negeri Malang yang sudah menempuh matakuliah praktikum pemesinan untuk menjawab persoalan dan mencari akar permasalahan yang terjadi ketika proses peminjaman alat, maka dari angket analisis kebutuhan yang sudah direspon oleh mahasiswa terdapat 95\% mahasiswa membutuhkan sebuah program online sebagai sarana kegiatan peminjaman peralatan. Sistem informasi peminjaman alat dengan menggunakan sistem web dapat mengelola data alat kerja dan administrasi peminjaman. Karena dengan menggunakan web atau online, pekerjaan dapat diselesaikan dengan baik, cepat dan hasil yang sangat memuaskan. Dengan adanya sistem informasi ini, diharapkan informasi mengenai peminjaman alat dapat lebih mudah dan lebih cepat disampaikan karena dibantu oleh proses komputerisasi sehingga dapat membantu pekerjaan toolman serta dapat meningkatkan efektifitas dan efisiensi toolman dalam melayani proses peminjaman alat kerja. Salah satu keuntungan dari sistem ini mahasiswa juga dapat lebih bertanggung jawab terhadap peralatan yang dipinjam, karena dengan sistem ini peralatan dapat terpantau dengan baik mengenai siapa yang meminjam, kondisi awal dan akhir alat setelah dipinjam oleh mahasiswa.

Dari permasalahan yang telah diuraikan di atas, maka solusi yang yang dimaksudkan peneliti adalah membuat sebuah sistem inventory berbasis web yang digunakan pada praktikum pemesinan, sehingga dapat membantu kegiatan praktikum pemesinan lebih efektif dan efisien, maka dari itu untuk mengatasi permasalahan yang terjadi peneliti mengambil judul "Pengembangan Sistem Inventory Praktikum Pemesinan Berbasis Web di Laboratorium Pemesinan Jurusan Teknik Mesin Fakultas Teknik Universitas Negeri Malang.

\section{METODE}

Metode penelitian yang digunakan pada penelitian ini adalah metode penelitian dan pengembangan (research and development). Tujuan peneliti dalam penelitian dan pengembangan ini adalah mengembangkan sistem inventory parktikum pemesinan di laboratorium Teknik Mesin Universitas Negeri Malang. Menurut Sukmadinata (2006:164) Penelitian dan Pengembangan atau Research and Development adalah suatu proses atau langkah-langkah untuk mengembangkan suatu produk baru, atau menyempurnakan suatu produk yang telah ada yang dapat dipertanggungjawabkan. Langkah-langkah penelitian dan pengembangan yang digunakan pada penelitian ini adalah berdasarkan model ADDIE. Menurut Mulyatiningsih (2011: 185), langkah-langkah model ADDIE, adalah 1) Analysis (Analisis), 2) Desain (Perancangan), 3) Development (Pengembangan), 4) Implementation (Implementasi), dan 5) Evaluation (Evaluasi). Terdapat beberapa aspek dalam pembuatan produk ini, antara lain: desain uji coba, subjek uji coba, instrumen pengumpulan data dan teknik analisis data.

Desain uji coba dilakukan dalam 2 tahap secera keseluruhan, yaitu evaluasi para ahli kemudian dilanjutkan dengan uji lapangan. Proses validasi harus dilakukan oleh orang yang sesuai dan harus benar-benar mempunyai pengalaman dan menguasi 
dalam bidangnya masing-masing, sehingga nantinya ketika proses validasi peneliti akan mendapatkan masukan maupun komentar mengenai kekurangan dan kelemahan produk yang telah dikembangakan. Berdasarkan masukan maupun komentar dari para ahli tersebut, maka produk akan dilakukan revisi supaya produk yang dihasilkan nantinya benar-benar layak untuk digunakan pada saat uji lapangan. Dalam penelitian dan pengembangan ini, peneliti melibatkan 2 para ahli, yaitu ahli media dan ahli manajemen bengkel. Menurut Suparman (1997:216) jumlah subjek dalam uji coba lapangan adalah 15-30 orang. Uji lapangan pada penelitian dan pengembangan ini melibatkan 20 subjek, subjek yang dimaksud oleh peneliti adalah mahasiswa teknik mesin Universitas Negeri Malang yang telah menempuh mata kuliah praktikum pemesinan.

Subjek yang terlibat dalam penelitian dan pengembangan ini adalah mahasiswa jurusan teknik mesin Universitas Negeri Malang yang telah menempuh praktikum pemesinan. Objek uji coba pada penelian dan pengembangan ini adalah program sistem inventory praktikum pemesinan berbasis web pada laboratorium pemesinan Universitas Negeri Malang.

Jenis data dari uji coba produk yang digunakan dalam penelitian dan pengembangan sistem inventory praktikum pemesinan berbasis web di laboratorium pemesinan Universitas Negeri Malang adalah data kuantitatif dan kualitatif. Data tersebut diperoleh dari tahap validasi ahli dan uji lapangan. Data kuantitatif diperoleh dari tahap validasi ahli media dan ahli manajemen bengkel serta uji coba lapangan kepada mahasiswa teknik mesin Universitas Negeri Malang. Data kualitatif diperoleh dari umpan balik yang diberikan oleh validasi ahli yang berupa kritik dan saran mengenai program sistem inventory praktikum pemesinan berbasis web di laboratorium teknik mesin Universitas Negeri Malang.

Instrumen pengumpulan data dalam penelitian dan pengembangan ini adalah teknik observasi dan angket. Observasi yang dilakukan dalam penelitian dan pengembangan ini adalah dengan melakukan pengamatan kepada mahasiswa teknik mesin pada saat melakukan praktikum pemesinan. Observasi sebagai teknik pengumpulan data tidak hanya berpusat pada mahasiswa, tetapi juga pada objek-objek yang lain (Sugiyono, 2013:203). Peneliti melakukan observasi melalui pengamatan dengan tujuan untuk mengumpulkan data mengenai permasalahan yang telah terjadi dan memerlukan pemecahan masalah kepada mahasiswa teknik mesin Universitas Negeri Malang. Menurut Sugiyono (2013:199) angket atau kuisioner merupakan teknik pengumpulan data dengan memberikan pertanyaan tertulis kepada subjek untuk dijawab. Dalam penelitian dan pengembangan ini peneliti menggunakan angket untuk mengumpulkan data pada saat: 1) validasi oleh para ahli yang meliputi ahli materi dan ahli media, 2) uji coba produk kepada 20 mahasiswa teknik mesin Universitas Negeri Malang. Angket yang digunakan dalam penelitian dan pengembangan ini yaitu tertutup.

Analisis data merupakan suatu kegiatan yang sangat penting yang harus dilaksanakan dalam penelitian dengan kecermatan dan ketelitian. Oleh karena itu, data yang diperoleh haruslah valid. Analisis data adalah proses mencari dan menyusun secara sistematis data yang diperoleh dari hasil observasi, kuisioner dan bahan-bahan lain sehingga mudah untuk dipahami dan temuannya dapat diinformasikan kepada orang lain (Sugiyono, 2013:244). Teknik analisis data yang digunakan dalam penelitian dan pengembangan ini adalah teknik analisis deskriktif kuantitatif yang berupa presentase. Rumus yang digunakan dalam penelitian ini adalah:

$$
V=\frac{T S E V}{S-\max } \times 100 \%
$$

(Akbar \& Sriwiyana, 2010:213)

Keterangan:

$\mathrm{V} \quad=$ Validitas

TSEV = Total skor empirik validator

S-max $=$ Skor maksimal yang diharapkan

Adinugroho (2012) dalam skripsinya yang berjudul "Perancangan Sistem Informasi Peminjaman Alat Di Kamar Alat Intercamp ATMI Surakarta", mengatakan bahwa pengelolaan alat kerja dan proses peminjaman alat masih bersifat manual dan berjalan cukup baik. Namun terdapat beberapa kendala terkait proses peminjaman alat kerja. Kesulitan tersebut dikelompokkan dalam dua kelompok yaitu teknis dan administratif. Kelompok teknis merupakan kesulitan - kesulitan yang disebkan oleh kondisi teknis, yang berkaitan erat dengan kondisi, persediaan dan keterbatasan alat kerja. Kelompok administratif merupakan kesulitan - kesulitan yang disebabkan oleh kegiatan administrasi dan kualitas pelayanan dalam proses peminjaman. Masalah tersebut dapat diatasi dengan menggunakan sistem informasi peminjaman alat berbantukan komputer yang dapat mengelola alat kerja dan administrasi peminjaman. 
Setiowati (2014) dalam skripsinya yang berjudul "Pengembangan Sistem Informasi Inventarisasi Jurusan Teknik Elektro Fakultas Teknik Universitas Negeri Malang”, mengembangkan sistem informasi yang meliputi proses peminjaman alat, penggunaan bahan habis pakai dan manajemen inventaris peralatan. Hasil yang diperoleh dari pengembangan ini adalah berupa software yang dapat melakukan proses pelayanan peminjaman peralatan dan bahan habis pakai oleh pengguna (mahasiswa, dosen dan pegawai), dan inventarisasi oleh laboran.

Setyawan (2015) dalam skripsinya yang berjudul "Pengembangan Sistem Inventarisasi Sarana Laboratorium Jurusan Administrasi Pendidikan Universitas Negeri Malang Berbasis Teknologi Informasi”, mengatakan bahwa keberhasilan program pendidikan melalui proses belajar mengajar sangat dipengaruhi oleh banyak faktor, salah satu diantaranya adalah tersedianya sarana dan prasarana pendidikan yang memadai disertai pemanfaatan dan pengelolaan secara optimal. Dalam penelitiannya setyawan juga mengemukakan proses inventarisasi di laboratorium pada umumnya banyak ditemui kesalahan pencatatan yang dilakukan secara manual, sehingga informasi yang diperoleh tidak sama dengan kenyataan yang ada. Hasil penelitian yang diperoleh dari permasalahan tersebut adalah membuat sebuah software yang dapat mengelola sarana atau tata usaha laboratorium.

Fuadah (2015) mengungkapkan layanan akademik dan administrasi akademik dalam perguruan tinggi meliputi layanan kemahasiswaan, pendidikan kelas, dan laboratorium. Laboratorium memiliki tanggung jawab dalam memberikan layanan akademik, serta bertanggung jawab dalam mengelola administrasinya dengan baik. Administrasi laboratorium juga meliputi informasi inventaris barang yang ada di laboratorium. Sebagai salah satu kegiatan akademik, pengelolaan laboratorium memerlukan sarana yang mampu membantu para teknisi dalam mengelola informasi. Sistem yang diperlukan adalah sistem yang dapat memudahkan semua pihak baik teknisi, mahasiswa, maupun dosen untuk memanfaatkan informasi inventaris laboratorium.

Safrianto (2017) dalam skripsinya yang berjudul "Pengembangan Program Manajemen Bengkel Berbasis Information Technology (IT) Pada Bengkel Pemesinan SMK Negeri 3 Boyolangu”, mengatakan bahwa dalam pembelajaran praktikum yang dilaksanakan di bengkel pemesinan mempunyai program manajemen bengkel tersendiri, salah satunya adalah program manajemen peminjaman alat bantu dan bahan praktikum yang akan digunakan dalam kegiatan praktikum yang prosedurnya masih bersifat manual. Proses peminjaman tersebut mempunyai dampak negatif seperti catatan yang mudah hilang, kondisi peralatan yang tidak sesuai dengan yang dicatat, dan dirasa kurang efektif karena peserta didik harus menulis secara manual daftar peralatan yang akan dipinjam dan pihak laboran harus mengecek ulang alat dan bahan yang tersedia. Maka dari itu diperlukan suatu pengembangan yang dapat meningkatkan mutu manajemen peralatan.

Manajemen inventarisasi pada bengkel - bengkel praktikum saat ini sangat perlu diperhatikan terutama dalam pengelolaannya serta dibutuhkan media untuk pendataan barang - barang yang terdapat dalam bengkel praktikum tersebut. Berdasarkan penelitian di atas, dapat disimpulkan bahwa pembuatan program sistem inventory dapat membantu dalam pengelolaan data peralatan yang ada di laboratorium pemesinan dan dengan berbasis web program tersebut dapat lebih mudah digunakan karena dapat dioperasikan dalam komputer manapun.

\section{PEMBAHASAN}

Deskripsi Produk Hasil Pengembangan

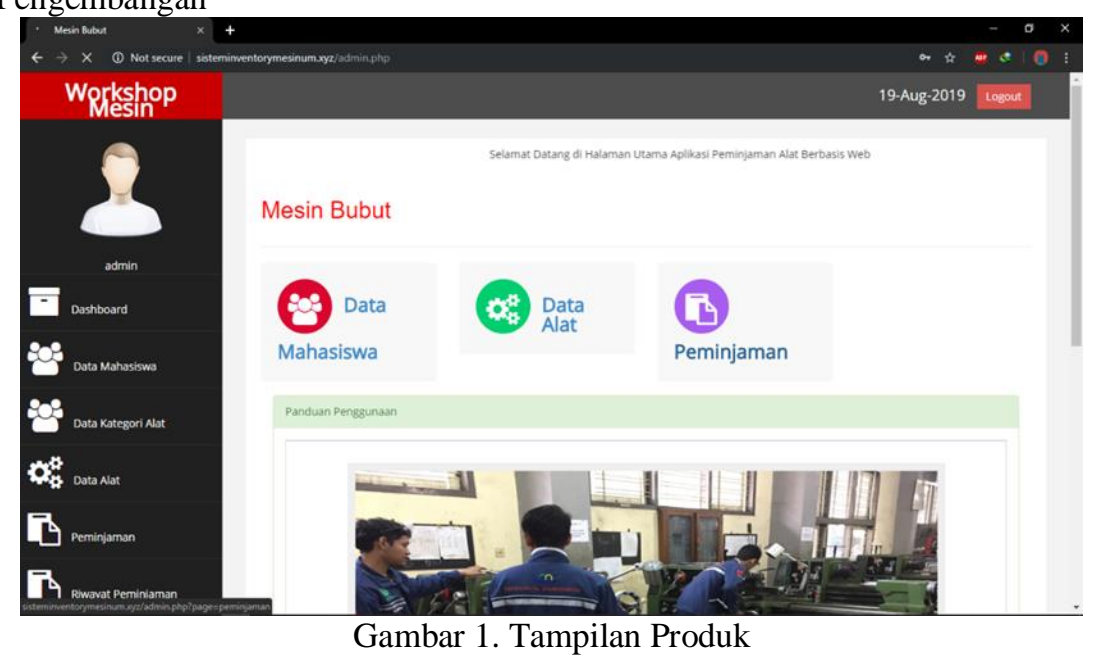


Hasil pengembangan berupa produk berbentuk program sistem inventory praktikum pemesinan berbasis web di laboratorium pemesinan. Tampilan produk yang telah dikembangkan dapat dilihat pada gambar 1. Program sistem inventory praktikum pemesinan berbasis web di laboratorium pemesinan dengan cara membuka situs pada web dengan alamat "sisteminventorymesinum.xyz". Pada saat login, terlebih dahulu harus memasukkan akun beserta password. Halaman login disertakan kode keamanan yang bertujuan untuk pengamanan dalam membuka aplikasi supaya aplikasi tidak disalahgunakan oleh pihak diluar yang berwenang. Tampilan halaman home terdapat 5 pilihan tombol yang berisi tentang data-data informasi yang diperlukan pada saat praktikum pemesinan dan juga terdapat 3 tombol yang berisi tentang data mahasiswa, data alat dan data peminjaman. Tampilan home menampilkan panduan pengguna yang berfungsi untuk membantu para pengguna awal yang kesulitan memprogram aplikasi, pada tampilan home juga terdapat tanggal web tersebut diakses yang terletak pada pojok kanan atas tampilan home.

Halaman data mahasiswa berfungsi untuk menginput data nama-nama mahasiswa yang sedang melaksanakan praktikum pemesinan dan untuk mengetahui jumlah mahasiswa yang sedang mengampu matakuliah praktikum pemesinan pada minggu tertentu. Tampilan halaman data mahasiswa terdapat beberapa tombol yang dapat dipilih diantaranya adalah: Tombol ubah yang berfungsi untuk merubah data mahasiswa yang melaksanakan praktikum atau untuk merubah data mahasiswa apabila ada data yang kurang benar. Tombol hapus berfungsi untuk menghapus data mahasiswa yang melaksanakan kegiatan praktikum pemesinan. Tombol tambah data yang berfungsi untuk menginput data mahasiswa yang akan melaksanakan kegiatan praktikum pemesinan pada laboratorium pemesinan. Tombol export berfungsi sebagai pengubah database dari data mahasiswa ke dalam bentuk dokumen agar nantinya data dapat dicetak dan dapat disimpan oleh pihak laboran.

Halaman data kategori alat berfungsi untuk mengelompokkan nama alat yang ada pada mesin yang digunakan saat praktikum pemesinan. Halaman data alat berfungsi menginput dan menampilkan peralatan yang tersedia di laboratorium pemesinan yang digunakan pada saat praktikum pemesinan. Halaman data alat menampilkan kondisi peralatan yang akan dipinjam, sehingga laboran dapat mengecek kondisi alat sebelum dan setelah dipinjam oleh mahasiswa. Tampilan data alat terdapat tombol export yang berfungsi untuk mencetak database ke dalam bentuk dokumen yang akan memudahkan laboran dalam pendataan peralatan.

Halaman data peminjaman alat berfungsi untuk memproses data peminjaman peralatan yang akan dipinjam oleh mahasiswa, dan juga menampilkan minggu serta blok praktikum mahasiswa yang melaksanakan praktikum pemesinan. Tampilan data peminjaman alat terdapat beberapa menu yang tersedia diantaranya adalah: Tombol tambah data yang berfungsi untuk menginput data peralatan yang akan dipinjam oleh mahasiswa yang melaksanakan praktikum pemesinan. Tombol ubah yang berfungsi untuk merubah data peminjaman apabila terjadi kesalahan dalam penginputan data peminjaman peralatan. Tombol dikembalikan yang berfungsi untuk memproses pengembalian peralatan apabila mahasiswa telah mengembalikan peralatan yang telah dipinjam pada saat praktikum pemesinan, maka tombol dikembalikan dapat dipilih. Tombol export berfungsi untuk mencetak data peminjaman peralatan ke dalam bentuk dokumen dan juga dapat memudahkan laboran dalam mendokumentasikan data-data peminjaman peralatan.

Halaman riwayat peminjaman berfungsi untuk melihat riwayat peminjaman peralatan pada saat praktikum pemesinan di laboratorium pemesinan. Halaman riwayat peminjaman dilengkapi dengan tombol export yang memudahkan laboran dalam mendokumentasikan data tanpa melakukan penulisan secara manual yang dapat menambah waktu.

Pengujian dilaksanakan dengan validasi, yaitu dengan memberikan angket yang berisi butir-butir soal tentang isi dari program sistem inventory praktikum pemesinan berbasis web di laboratorium pemesinan dan meminta pendapat, kritik serta saran dari ahli materi dan ahli media. Uji kelayakan produk oleh ahli media bertujuan untuk mengetahui kelayakan produk berupa program sistem inventory praktikum pemesinan berbasis web di laboratorium pemesinan yang dilihat dari sisi materi sehingga layak digunakan sebagai inventarisasi peralatan pada laboratorium pemesinan Jurusan Teknik Mesin FT UM. Uji kelayakan produk oleh ahli media bertujuan untuk mengetahui kelayakan produk berupa program sistem inventory praktikum pemesinan berbasis web di laboratorium pemesinan yang dilihat dari sisi media sehingga layak digunakan sebagai inventarisasi peralatan pada laboratorium pemesinan Jurusan Teknik Mesin FT UM.

Uji kelayakan ahli materi pada program sistem inventory praktikum pemesinan berbasis web di laboratorium pemesinan melibatkan satu ahli materi yaitu dosen di Jurusan Teknik Mesin FT UM yang ditinjau dari beberapa aspek, diantaranya: 1) Aspek Sistem Informasi Manajemen, dan 2) Aspek Manajemen Inventori. 2 aspek tersebut yang berisi tentang butir-butir soal mengenai program sistem inventory praktikum pemesinan berbasis web di laboratorium pemesinan. Berikut adalah tabel hasil validasi kelayakan prodek oleh ahli materi. 
Tabel 2. Skor Validasi Ahli Materi

\begin{tabular}{rrrrrrrr}
\hline No & Skor & \multicolumn{1}{c}{ No } & Skor & \multicolumn{1}{c}{ No } & \multicolumn{1}{c}{ Skor } & No & Skor \\
\hline 1. & 2 & 5. & 2 & 9. & 3 & 13. & 4 \\
2. & 4 & 6. & 4 & 10. & 3 & 14. & 3 \\
3. & 4 & 7. & 3 & 11. & 4 & 15. & 4 \\
4. & 3 & 8. & 4 & 12. & 4 & 16. & 4 \\
\hline
\end{tabular}

Data hasil penelitian produk oleh ahli media yang berupa skor yang dikonversikan ke dalam interval skor skala empat. Berdasarkan hasil kelayakan produk oleh ahli media diketahui bahwa skor maksimum adalah sebesar 64 dan total skor minimum sebesar 16 .

1. Data dari hasil uji kelayakan berdasarkan dari aspek sistem informasi manajemen (nomor butir 1-6) memiliki 6 butir soal yang akan dinilai. Data dari aspek sistem informasi manajemen memiliki skor maksimum sebesar 24 dan skor minimum sebesar 6.

2. Data dari hasil uji kelayakan berdasarkan dari aspek manajemen inventori (nomor butir 7-16) memiliki 10 butir soal yang akan dinilai. Data dari aspek manajemen inventori memiliki skor maksimum sebesar 40 dan skor minimum sebesar 10.

Data hasil penilaian oleh ahli materi terhadap produk yang dinilai berdasarkan aspek sistem informasi manajemen, dan aspek manajemen inventori yang telah dikonversikan ke dalam beberapa kategori dapat dilihat pada tabel 3.

Tabel 3. Hasil Uji Kelayakan Produk Oleh Ahli Materi

\begin{tabular}{lllllll} 
No. & Aspek & Skor Validator & Skor Max & Hasil & Skala \% & Kategori \\
\hline 1. & Sistem Informasi Manajemen & 19 & 24 & 0,792 & $79,2 \%$ & Valid \\
2. & Manajemen Inventori & 36 & 40 & 0,9 & $90 \%$ & Valid \\
\hline \multicolumn{2}{c}{ Skor Total } & $\mathbf{5 5}$ & $\mathbf{6 4}$ & $\mathbf{0 , 8 5 9}$ & $\mathbf{8 5 , 9 \%}$ & Valid \\
\hline
\end{tabular}

Data hasil penelitian produk oleh ahli materi yang berupa skor yang dikonversikan ke dalam interval skor skala empat. Berdasarkan perhitungan pada tabel 2, persentase hasil akhir dari uji kelayakan produk program sistem inventory praktikum pemesinan berbasis web di laboratorium pemesinan adalah $85,9 \%$, maka penilaian dari program sistem inventory praktikum pemesinan berbasis web di laboratorium pemesinan berdasarkan angket dari sisi materi termasuk dalam kriteria sangat valid sehingga layak untuk digunakan. Terdapat beberapa revisi pada program sistem inventory praktikum pemesinan berbasis web di laboratorium pemesinan adalah jenis peralatan yang ada dalam program sistem inventory praktikum pemesinan berbasis web di laboratorium pemesinan ditambahkan.

Uji kelayakan ahli media pada program sistem inventory praktikum pemesinan berbasis web di laboratorium pemesinan melibatkan satu ahli media yaitu dosen di Jurusan Teknik Mesin FT UM yang ditinjau dari beberapa aspek, diantaranya: 1) Aspek Kemanfaatan, 2) Aspek Tampilan, 3) Aspek Pemrograman dan 4) Aspek Konsistensi. 4 aspek tersebut yang berisi tentang butir-butir soal mengenai program sistem inventory praktikum pemesinan berbasis web di laboratorium pemesinan. Berikut adalah tabel hasil validasi kelayakan prodek oleh ahli media.

Tabel 4. Skor Validasi Ahli Media

\begin{tabular}{llllllll}
\hline No & Skor & No & Skor & No & Skor & No & Skor \\
\hline 1. & 4 & 9. & 4 & 17. & 4 & 25. & 4 \\
2. & 4 & 10. & 4 & 18. & 4 & 26. & 4 \\
3. & 4 & 11. & 4 & 19. & 4 & 27. & 4 \\
4. & 4 & 12. & 4 & 20. & 4 & 28. & 4 \\
5. & 4 & 13. & 4 & 21. & 4 & 29. & 4 \\
6. & 4 & 14. & 4 & 22. & 4 & 30. & 4 \\
7. & 4 & 15. & 4 & 23. & 4 & 31. & 3 \\
8. & 4 & 16. & 4 & 24. & 4 & 32. & 4 \\
\hline
\end{tabular}


Data hasil penelitian produk oleh ahli media yang berupa skor yang dikonversikan ke dalam interval skor skala empat. Berdasarkan hasil kelayakan produk oleh ahli media diketahui bahwa skor maksimum adalah sebesar 128 dan total skor minimum sebesar 32 .

1. Data dari hasil uji kelayakan berdasarkan dari aspek kemanfaatan (nomor butir 1-9) memiliki 9 butir soal yang akan dinilai. Data dari aspek kemanfaatan memiliki skor maksimum sebesar 36 dan skor minimum sebesar 9.

2. Data dari hasil uji kelayakan berdasarkan dari aspek tampilan (nomor butir 10-17) memiliki 8 butir soal yang akan dinilai. Data dari aspek tampilan memiliki skor maksimum sebesar 32 dan skor minimum sebesar 8 .

3. Data dari hasil uji kelayakan berdasarkan dari aspek pemrograman (nomor butir 18-26) memiliki 9 butir soal yang akan dinilai. Data dari aspek pemrograman memiliki skor maksimum sebesar 36 dan skor minimum sebesar 9.

4. Data dari hasil uji kelayakan berdasarkan dari aspek konsistensi (nomor butir 27-32) memiliki 6 butir soal yang akan dinilai. Data dari aspek konsistensi memiliki skor maksimum sebesar 24 dan skor minimum sebesar 6.

Data hasil penilaian oleh ahli media terhadap produk yang dinilai berdasarkan aspek kemanfaatan, aspek tampilan, aspek pemrograman, dan aspek konsistensi yang telah dikonversikan ke dalam beberapa kategori dapat dilihat pada tabel 5 .

Tabel 5. Hasil Uji Kelayakan Produk Oleh Ahli Media

\begin{tabular}{lllllll}
\hline No. & Aspek & $\begin{array}{c}\text { Skor } \\
\text { Validator }\end{array}$ & $\begin{array}{c}\text { Skor } \\
\text { Max }\end{array}$ & Hasil & Skala \% & Kategori \\
\hline 1. & Kemanfaatan & 36 & 36 & 1 & $100 \%$ & Valid \\
2. & Tampilan & 32 & 32 & 1 & $100 \%$ & Valid \\
3. & Pemrograman & 36 & 36 & 1 & $100 \%$ & Valid \\
4. & Konsistensi & 23 & 24 & 0,958 & $95,8 \%$ & Valid \\
\hline \multirow{2}{*}{ Ket. } & \multirow{2}{*}{ Aspek } & Skor & Skor & Hasil & Skala \% & Kategori \\
& & Validator & Max & & & Valid \\
\hline
\end{tabular}

Berdasarkan perhitungan pada tabel 2, persentase hasil akhir dari uji kelayakan produk program sistem inventory praktikum pemesinan berbasis web di laboratorium pemesinan adalah 99,8\%, maka penilaian dari program sistem inventory praktikum pemesinan berbasis web di laboratorium pemesinan berdasarkan angket dari sisi media termasuk dalam kriteria sangat valid sehingga layak untuk digunakan.

Terdapat beberapa perbaikan pada program sistem inventory praktikum pemesinan berbasis web di laboratorium pemesinan adalah:

1. Pengisian data peralatan by online sudah menarik.

2. Sajian atau tampilan untuk print out akan lebih lengkap jika tertera kop institusi dan ditambahkan dengan tanda tangan laboran sebagai penanggung jawab.

\section{Analisis Data Kualitas Produk}

Uji kualitas produk oleh pengguna dilaksanakan dengan melibatkan 20 mahasiswa Jurusan Teknik Mesin FT UM yang telah melaksanakan kegiatan praktikum pemesinan. Instrumen pengumpulan data yang digunakan berupa angket/kuisioner yang sebelumnya telah dikembangkan kemudian diperbaiki oleh peneliti dengan dilakukan validasi instrument penelitian oleh dosen validasi ahli materi dan dosen validasi ahli media selaku dosen Jurusan Teknik Mesin FT UM.

Angket respon penilaian mahasiswa Jurusan Teknik Mesin FT UM berisi penilaian dari produk yang ditinjau dari aspek materi dan media. Berdasarkan data hasil penilaian responden mahasiswa, maka dapat disusun tabel analisis kelayakan produk sebagai berikut. 
Tabel 6. Hasil Uji Produk oleh Responden

\begin{tabular}{lccclll}
\hline No. & Aspek & $\begin{array}{c}\text { Skor } \\
\text { Responden }\end{array}$ & $\begin{array}{c}\text { Skor } \\
\text { Max }\end{array}$ & Hasil & Skala \% & Kategori \\
\hline 1. & Materi & 693 & 720 & 0,9625 & $96,25 \%$ & Valid \\
2. & Media & 769 & 800 & 0,96125 & $96,125 \%$ & Valid \\
\hline & Skor Total & $\mathbf{1 4 6 2}$ & $\mathbf{1 5 2 0}$ & $\mathbf{0 , 9 6 1 8}$ & $\mathbf{9 6 , 1 8 \%}$ & Valid \\
\hline
\end{tabular}

Berdasarkan perhitungan data yang diperoleh perhitungan dari penilaian responden terhadap program sistem inventory praktikum pemesinan berbasis web di laboratorium pemesinan di atas, persentase perhitungan hasil akhir pada tabel 4.6 adalah 96,18\%, maka penilaian program sistem inventory praktikum pemesinan berbasis web di laboratorium pemesinan berdasarkan butir instrumen pada angket yang dibuat termasuk dalam tingkat yang valid sehingga program ini dikatakan untuk layak digunakan pada laboratorium pemesinan Jurusan Teknik Mesin FT UM.

\section{Hasil Analisis Kebutuhan}

Penyusunan suatu program sistem inventory praktikum pemesinan berbasis web di laboratorium pemesinan diperlukan pula analisis kebutuhan sehingga penyusunan program sistem inventory praktikum pemesinan berbasis web di laboratorium pemesinan tersebut memiliki tujuan yang pasti dan isi yang sesuai dengan inventarisasi yang ada di laboratorium pemesinan. Tujuan instruksional umum yang ingin dicapai adalah agar laboran dapat memahami sistem dalam program sistem inventory praktikum pemesinan berbasis web di laboratorium pemesinan terutama dalam proses inventarisasi dan peminjaman alat. Berikut adalah data analisis kebutuhan dengan melibatkan 20 mahasiswa Jurusan Teknik Mesin FT UM.

\section{PENUTUP}

Produk pengembangan program sistem inventory praktikum pemesinan berbasis web di laboratorium pemesinan jurusan teknik mesin FT UM yaitu berupa produk inventaris peralatan pemesinan dan program peminjaman peralatan pemesinan yang digunakan laboran dan mahasiswa guna membantu kegiatan praktikum pemesinan. Pada program sistem inventory praktikum pemesinan berbasis web di laboratorium pemesinan menggunakan sistem online yang dimana laboran dan mahasiswa dapat mudah mengakses program saat berlangsungnya proses kegiatan praktikum pemesinan. Penggunaan web, pekerjaan laboran dapat dikerjakan dengan baik, cepat dan memuaskan. Dengan adanya sistem informasi ini, informasi mengenai persediaan peralatan, kondisi peralatan serta peminjaman peralatan dapat mudah dan lebih cepat disampaikan. Program sistem inventory praktikum pemesinan berbasis web di laboratorium pemesinan dapat menjamin keamanan data peralatan praktikum pemesinan karena program ini dilengkapi dengan akses login menggunakan user id dan password. Program ini ditampilkan secara menarik dan kompleks agar nantinya dapat mudah untuk saat dioperasikan.

Berdasarkan data validasi dari 2 ahli (ahli materi dan ahli media) terdapat beberapa revisi terhadap program yang telah dikembangkan, antara lain dengan menambahkan peralatan yang ada pada program agar ketika dilakukan uji coba lapangan program mendapatkan skor yang maksimal dari responden. Revisi pada bagian export to document untuk ditambahkan kop institusi, tanda tangan laboran dan tanggal dokumen dicetak, hal ini bertujuan untuk membantu laboran dalam mendata peralatan dengan baik. Dari hasil validasi skor yang didapatkan adalah $85,9 \%$ dari ahli materi dan $99,8 \%$. Skor tersebut menunjukkan bahwa program sistem inventory praktikum pemesinan berbasis web di laboratorium pemesinan memiliki tingkat validitas dalam kategori sangat valid dan dapat dipergunakan.

Selain kelebihan dan kelemahan dari program ini tentunya tidak terlepas dari keterbatasan penelitian. Keterbatasan penelitian dalam pengembangan ini relatif berdampak pada kualitas program yang dikembangkan, namun dari berbagai kendala yang dihadapi, semoga penelitian dan pengembangan ini dapat bermanfaat dan dapat dijadikan pertimbangan dalam pelaksanaan penelitian dan pengembangan selanjutnya. 


\section{DAFTAR RUJUKAN}

Adinugroho, G. 2012. Perancangan Sistem Informasi Peminjaman Alat Di Kamar Alat Intercamp ATMI Surakarta. Surakarta: Universitas Sebelas Maret.

Akbar, S dan Sriwiyana. 2010. Pengembangan Kurikulum dan Pembelajaran Ilmu Pengetahuan Sosial. Yogyakarta: Cipta Media.

Fuadah, R. 2015. Pengembangan dan Analisis Kualitas Sistem Informasi Inventaris Laboratorium Jurusan Pendidikan Teknik elektronika FT UNY "Laboratory" Berbasis Web. Yogyakarta: UNY.

Indra, T.R. 2013. Komputerisasi Laboratorium Teknik Mesin di Fakultas Teknik Universitas Negeri Malang Melalui Sistem Informasi Manajemen (SIM). Malang: Universitas Negeri Malang.

Mulyatiningsih, E. 2011. Riset Terapan: Bidang Pendidikan dan Teknik. Yogyakarta: UNY Press.

Nurhadi, D. 2012. Pengembangan Standart Operation Procedure (SOP) Laboratorium Teknik Mesin di Jurusan Mesin Fakultas Teknik Universitas Negeri Malang. Jurnal Teknik Mesin. 20(2), 23 - 29.

Ristono. 2009. Manajemen Persediaan. Yogyakarta: Graha Ilmu.

Safrianto, V. 2017. Pengembangan Program Manajemen Bengkel Berbasis Information Technology (IT) Pada Bengkel Pemesinan SMK Negeri 3 Boyolangu. Skripsi tidak diterbitkan. Malang: FT UM.

Setiowati, S. 2014. Pengembangan Sistem Informasi Inventarisasi Jurusan Teknik Elektro Fakultas Teknik Universitas Negeri Malang. Skripsi tidak diterbitkan. Malang: FT UM.

Setyawan, R. 2015. Pengembangan Sistem Inventarisasi Sarana Laboratorium Jurusan Administrasi Pendidikan Universitas Negeri Malang Berbasis Teknologi Informasi. Skripsi tidak diterbitkan. Malang: FT UM.

Sugiyono. 2013. Metode Penelitian Pendidikan Pendekatan Kuantitatif, Kualitatif, dan R\&D. Bandung: Alfabeta.

Sukmadinata. 2006. Metode Penelitian Kualitatif. Bandung: Graha Aksara.

Suparman, A. 1997. Model-model Pembelajaran Interaktif. Jakarta: Lembaga Administrasi Negara (LAN). 